\title{
Gallibacterium anatis: Moleculer Detection of Tetracycline Resistance and Virulence Gene
}

\author{
Ozlem Sahan Yapicier ${ }^{1 *}$ and Sibel Yaman ${ }^{2}$ \\ ${ }^{\text {I} B u r d u r}$ Mehmet Akif Ersoy University, Faculty of Veterinary Medicine, Department of Microbiology, 15030, Burdur, Turkey \\ ${ }^{2}$ Ankara University, The Health Sciences Institute, Department of Microbiology, Ankara, Turkey \\ *Corresponding author's Email: ozlem-sahan@ hotmail.com; ORCID ID: 0000-0003-3579-9425
}

Received: 22 April 2020

Accepted: 28 May. 2020

\begin{abstract}
Gallibacterium anatis causes infections in the reproductive tract of egg-laying hens and it is associated with increased mortality and decreased egg production. For this study we used singeleplex and multiplex PCR with specific primers to assess the presence of tetracycline resistance (Tcr) (tet A, B, C, D, E, G, H, K, L, M, O, S, P, Q and X), virulence [cytotoxic (RTX-like toxin, $g t x A$ ) and fimbrial (flfA)] genes and antibiotic resistance in G. anatis isolates. Among the 20 isolates tested, the highest antimicrobial resistance patterns were observed in erythromycin, streptomycin, tilmicosin $(100 \%)$ followed by colistin sulphate $(65 \%)$, cephalexin and tulathromycin (50\%). Among 20 isolates examined, $10(50 \%)$ carried tetracycline resistance genes, 7 (35\%) had tet $(\mathrm{B}), 2(10 \%)$ had $\operatorname{tet}(\mathrm{G})$, and $1(5 \%)$ had tet(A), (D), (M) or (L). Of these $G$.anatis isolates were carried out $6(30 \%)$ gtxA but none of flfA gene. Based on present results, it is concluded that virulence and Tcr genes could contribute to pathogencity of G. anatis, which is a major risk to poultry health.
\end{abstract}

Key words: Antibiotic resistance, G. anatis, Poultry, Virulence genes, Tetracycline resistance genes

\section{INTRODUCTION}

Major health problems in the poultry industry can affect egg production. In particular, infectious diseases can reduce egg production and egg quality by directly affecting the reproductive system of hens. Such diseases also can indirectly diminish the overall health status of poultry (Clauer, 2009). Gallibacterium anatis (G. anatis) is a resident of normal microflora of the lower genital and upper respiratory tract in chickens and many other avian species (Bojesen et al., 2004; Rzewuska et al., 2007; Jones et al., 2013; Paudel et al., 2013; Persson and Bojesen 2015; Lawal et al., 2018). Decreased egg production associated with salpingitis, respiratory system problems and mortality in commercial laying hens therefore, $G$. anatis infections have been the topic of researchers' works in recent years (Bojesen et al., 2011a; Sing, 2016; Chaveza et al., 2017). The knowledge of bacteria-host interactions and antimicrobial susceptibility to G. anatis in laying hens remains limited (Bisgaard et al., 2009; Johnson et al., 2013). Among the most important $G$. anatis virulence factors involved in colonization and invasion of the epithelium in the trachea, oropharyngeal tissues and oviduct are the IgG destructive protease, RTX-like toxin, gtxA and hemagglutinin, which suppress the host immune response (Vaca et al., 2011; Lucio et al., 2012). Bacterial fimbria are also important not only as a virulence factor, but as a target for preventative vaccines (Kudirkiene et al., 2014; Sorour et al., 2015). Tetracycline resistance determinants (Tcrs) are widespread among both Gram negative organisms and Pasteurellaceae family and are often found in multi-drug resistant bacterial species (Levy et al., 1989; Roberts, 1996). To better understand G. anatis pathogenicity in poultry, this study amied to determine the prevalence of Tcr genes and virulence-specific factor genes in G. anatis isolates from laying hens.

\section{MATERIAL AND METHODS}

\section{Bacterial Isolates}

In the present study, 20 Gallibacterium anatis isolates from laying hens obtained from the previous study at the Department of Microbiology, Faculty of Veterinary Medicine, Mehmet Akif Ersoy University, Burdur, Turkey were analysed (Yaman and Sahan Yapicier, 2019). 


\section{Gallibacterium anatis Strains}

G. anatis F149T (non-hemolytic strain, ATCC 43329) and 12656-12 strain (hemolytic strain) was used for analysis in this study.

\section{Antimicrobial Susceptibility Testing}

Antimicrobial susceptibility test was carried out by the agar disk diffusion method on Mueller-Hinton agar (Oxoid Ltd, Hampshire, UK) supplemented with 5\% sheep blood according to the guidelines from Clinical and Laboratory Standards Institute (CLSI, 2017). The following antibiotics (spiramycin and tulatromycin, Bioanalyse, Turkey), 18 out of 20 (Oxoid, UK) commonly used in veterinary medicine were selected: ampicillin

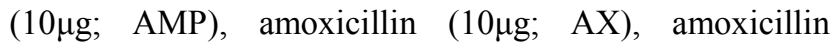
clavulanic acid $(30 \mu \mathrm{g} ; \mathrm{AMC})$, cephalexin $(30 \mu \mathrm{g} ; \mathrm{CL})$, ceftiofur $(30 \mu \mathrm{g}$; FUR), ciprofloxacin $(5 \mu \mathrm{g}$; CIP), colistin sulphate $(10 \mu \mathrm{g} ; \mathrm{CT})$, doxycilin $(30 \mu \mathrm{g}$; DO), enrofloxacin

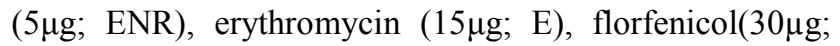
FFC), gentamicin $(10 \mu \mathrm{g} ; \mathrm{CN})$, tetracycline $(30 \mu \mathrm{g} ; \mathrm{T})$, penicillin (10units; P), spiramycin $(100 \mu \mathrm{g} ; \quad \mathrm{S})$,

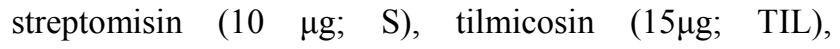
trimethoprim sulphamethoxazole $(25 \mu \mathrm{g} ; \quad \mathrm{TS})$,

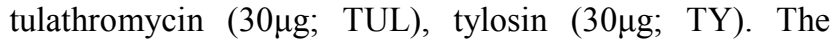
results were obtained by measuring the diameter of the growth inhibition zone around the antibiotic disc for each isolated bacteria and recorded as sensitive, intermediate and resistant according to the interpretive standards of CLSI and antimicrobials manufacturers' instructions. Isolates displaying resistance to $\geq 3$ antimicrobial agents tested were defined as exhibiting multi-drug resistance (MDR) (Tenover et al., 1987; Schwarz et al., 2010). E. coli ATCC 10536 was used as a quality control strain.

\section{Primers}

A primer pair specific for 14 tetracycline resistance genes and G. anatis virulence genes were listed in Tables 1 and 2 ( $\mathrm{Ng}$ et al. 2001; Bager et al. 2013; Paudel et al. 2013).

\section{DNA Extraction}

DNA extraction from $G$. anatis isolates were performed according to the instructions of the GeneJET Genomic DNA Purification Kit (Thermo Scientific, USA). DNAs were stored for use as template DNA at $-20^{\circ} \mathrm{C}$ until amplification.

\section{PCR Conditions}

Singeleplex PCR assay was carried out for virulence genes. $25 \mu \mathrm{l}$ reaction volumes containing $3 \mu \mathrm{MgCl}(25$
$\mathrm{mM}), 0.5 \mu \mathrm{l}$ dNTP $(10 \mathrm{mM}), 10$ pmols of primers and 0.2 $\mu \mathrm{l}$ Taq polymerase $(5 \mathrm{U} / \mu \mathrm{l})$. The following cycling conditions were used: $3 \mathrm{~min}$ at $94^{\circ} \mathrm{C}$, followed by 30 cycles of $1 \mathrm{~min}$ at $94^{\circ} \mathrm{C}$ (denaturation) and $1 \mathrm{~min}$ at $54^{\circ} \mathrm{C}$ (primer annealing), $1 \mathrm{~min}$ at $72^{\circ} \mathrm{C}$ (extension), and $7 \mathrm{~min}$ at $72^{\circ} \mathrm{C}$ (final extension). Multiplex PCR was performed for tetracycline resistant genes and these genes grouped (Group I: $\operatorname{tet}(\mathrm{B}), \operatorname{tet}(\mathrm{C})$ and tet(D); Group II: $\operatorname{tet}(\mathrm{A}), \operatorname{tet}(\mathrm{E})$ and $\operatorname{tet}(\mathrm{G}) ;$ Group III: $\operatorname{tet}(\mathrm{K}), \operatorname{tet}(\mathrm{L}), \operatorname{tet}(\mathrm{M}), \operatorname{tet}(\mathrm{O})$ and $\operatorname{tet}(\mathrm{S})$; Group IV: $\operatorname{tet} \mathrm{A}(\mathrm{P}), \operatorname{tet}(\mathrm{Q})$ and $\operatorname{tet}(\mathrm{X})) \operatorname{described}$ by $\mathrm{Ng}$ et al. (2001). Each multiplexed group's PCR reaction mix concentration and amplification conditions were carried out following the previous research (Zhao and Aoki, 1992).

Table 1. Tetracyline resistance specific primers

\begin{tabular}{|c|c|c|}
\hline Ters & primer sequence $\left(5^{\prime}-3{ }^{\prime}\right)$ & $\begin{array}{c}\text { Amplicon } \\
\text { size (bp) }\end{array}$ \\
\hline $\operatorname{tet}(\mathrm{A})$ & $\begin{array}{l}\text { GCT ACA TCC TGC TTG CCT TC } \\
\text { CAT AGA TCG CCG TGA AGA GG }\end{array}$ & 210 \\
\hline $\operatorname{tet}(\mathrm{B})$ & $\begin{array}{l}\text { TTG GTT AGG GGC AAG TTT TG } \\
\text { GTA ATG GGC CAA TAA CAC CG }\end{array}$ & 659 \\
\hline $\operatorname{tet}(\mathrm{C})$ & $\begin{array}{l}\text { CTT GAG AGC CTT CAA CCC AG } \\
\text { ATG GTC GTC ATC TAC CTG CC }\end{array}$ & 418 \\
\hline $\operatorname{tet}(\mathrm{D})$ & $\begin{array}{l}\text { AAA CCA TTA CGG CAT TCT GC } \\
\text { GAC CGG ATA CAC CAT CCA TC }\end{array}$ & 787 \\
\hline $\operatorname{tet}(\mathrm{E})$ & $\begin{array}{l}\text { AAA CCA CAT CCT CCA TAC GC } \\
\text { AAA TAG GCC ACA ACC GTC AG }\end{array}$ & 278 \\
\hline $\operatorname{tet}(\mathrm{G})$ & $\begin{array}{l}\text { GCT CGG TGG TAT CTC TGC TC } \\
\text { AGC AAC AGA ATC GGG AAC AC }\end{array}$ & 468 \\
\hline $\operatorname{tet}(\mathrm{G})$ & $\begin{array}{l}\text { CAG CTT TCG GAT TCT TAC GG } \\
\text { GAT TGG TGA GGC TCG TTA GC }\end{array}$ & 844 \\
\hline $\operatorname{tet}(\mathrm{K})$ & $\begin{array}{c}\text { TCG ATA GGA ACA GCA GTA CAG } \\
\text { CAG ATC CTA CTC CTT }\end{array}$ & 169 \\
\hline $\operatorname{tet}(\mathrm{L})$ & $\begin{array}{l}\text { TCG TTA GCG TGC TGT CAT TC } \\
\text { GTA TCC CAC CAA TGT AGC CG }\end{array}$ & 267 \\
\hline $\operatorname{tet}(\mathrm{M})$ & $\begin{array}{l}\text { GTG GAC AAA GGT ACA ACG AG } \\
\text { CGG TAA AGT TCG TCA CAC AC }\end{array}$ & 406 \\
\hline $\operatorname{tet}(\mathrm{O})$ & $\begin{array}{l}\text { AAC TTA GGC ATT CTG GCT CAC } \\
\text { TCC CAC TGT TCC ATA TCG TCA }\end{array}$ & 515 \\
\hline $\operatorname{tet}(\mathrm{S})$ & $\begin{array}{l}\text { CAT AGA CAA GCC GTT GAC C } \\
\text { ATG TTT TTG GAA CGC CAG AG }\end{array}$ & 667 \\
\hline $\operatorname{tet}(\mathrm{P})$ & $\begin{array}{l}\text { CTT GGA TTG CGG AAG AAG AG } \\
\text { ATA TGC CCA TTT AAC CAC GC }\end{array}$ & 676 \\
\hline $\operatorname{tet}(\mathrm{Q})$ & $\begin{array}{l}\text { TTA TAC TTC CTC CGG CAT CG } \\
\text { ATC GGT TCG AGA ATG TCC AC }\end{array}$ & 904 \\
\hline $\operatorname{tet}(\mathrm{X})$ & $\begin{array}{l}\text { CAA TAA TTG GTG GTG GAC CC } \\
\text { TTC TTA CCT TGG ACA TCC CG }\end{array}$ & 468 \\
\hline
\end{tabular}


Table 2. Spesific primers for virulence genes of G. anatis

\begin{tabular}{ccc}
$\begin{array}{c}\text { Virulence } \\
\text { genes }\end{array}$ & Primer sequence (5'-3') & $\begin{array}{c}\text { Amplicon } \\
\text { size (bp) }\end{array}$ \\
\hline GalNtx & $\begin{array}{c}\text { TGCGCAAGTGCTAAATGAAG } \\
\text { GGATAATCGTTGCGCTTTG }\end{array}$ & 925 \\
\hline \multirow{3}{*}{$f l f A$} & $\begin{array}{c}\text { CACCATGGGTGCATTTGCGGATGATC } \\
\text { C TATTCGTATGCGATAGTATAGTC }\end{array}$ & 538 \\
\hline
\end{tabular}

\section{Ethical Approval}

This study was approved by Animal Research Ethics Committee of Burdur Mehmet Akif Ersoy University, Burdur, Turkey (Protocol No. MAKU-HADYEK/ 2017314).

\section{RESULTS}

\section{Antimicrobial Susceptibility Test}

The highest antimicrobial resistance patterns in 20 isolates tested were observed for erythromycin, streptomycin, tilmicosin (100\%) followed by colistin sulphate (65\%), cephalexin and tulathromycin (50\%) which are shown in table 3. $100 \%$ of the G. anatis isolates exhibited sensitivity to doxycilline while $15 \%$ and $85 \%$, respectively, showed intermediate resistance to tetracycline.

\section{Genes}

\section{Molecular Detection of tet Genes and Virulence}

Twenty isolates of $G$. anatis contained $10(50 \%)$ tetracycline resistance, 7 (35\%) tet $(\mathrm{B}), 2(10 \%) \operatorname{tet}(\mathrm{G})$, $1(5 \%) \operatorname{tet}(\mathrm{A}),(\mathrm{D}),(\mathrm{M})$ and $(\mathrm{L}) .2(\% 10)$ were found to carry both $\operatorname{tet}(\mathrm{B})$ and $\operatorname{tet}(\mathrm{G}) ; 1(5 \%)$ were carried both tet(B), (D) and (A) genes (Figure 1). The amplification of genes by PCR showed that $6(30 \%)$ strains contains $g t x A$ and no flfA genes encoded. Based on the correlation of isolates; one of the two isolates carried both tet(B), (D) and $g t x$ gene and the other carried tet (B) and gtx genes.

Table 3. Antimicrobial resistance of $20 \mathrm{G}$. anatis isolates

\begin{tabular}{lccc}
\hline Items & $\mathbf{S}(\mathbf{n} \%)$ & $\mathbf{I}(\mathbf{n} \%)$ & $\mathbf{R}(\mathbf{n} \%)$ \\
\hline AMP & $20(100)$ & 0 & 0 \\
\hline AMC & $20(100)$ & 0 & 0 \\
\hline AX & $20(100)$ & 0 & 0 \\
\hline CIP & $15(75)$ & 0 & $5(25)$ \\
\hline CL & $12(50)$ & 0 & $12(50)$ \\
CN & $16(80)$ & 0 & $4(20)$ \\
\hline CT & $7(35)$ & 0 & $13(65)$ \\
\hline DO & $20(100)$ & 0 & 0 \\
\hline E & 0 & 0 & $20(100)$ \\
\hline ENR & $20(100)$ & 0 & 0 \\
\hline FFC & $20(100)$ & 0 & 0 \\
\hline FUR & $20(100)$ & 0 & 0 \\
\hline P & $20(100)$ & 0 & 0 \\
\hline SP & $15(75)$ & 0 & $5(25)$ \\
\hline S & 0 & 0 & $20(100)$ \\
\hline TE & 0 & $17(85)$ & $3(15)$ \\
\hline TIL & 0 & 0 & $20(100)$ \\
\hline TS & $19(95)$ & 0 & $1(5)$ \\
\hline TUL & $10(50)$ & 0 & $10(50)$ \\
\hline TY & $15(75)$ & 0 & $5(25)$ \\
\hline S: Sen & 0 & 0 & 0 \\
\hline
\end{tabular}

S: Sensitive, I: Intermediate, R: Resistant, AMP: Ampicillin, AMC: Amoxicillin clavulanic acid, AX: Amoxicillin, CIP: Ciprofloxacin, CL: Cephalexin, CN: Gentamicin, CT: Colistin sulphate, DO: Doxycillin, E: Erythromycin, ENR: Enrofloxacin, FFC: Florfenicol, FUR: Ceftiofur, P: Penicillin: SP: Spiramycin, S: Streptomisin, TE: Tetracycline, TIL:

Tilmicosin, TS: Trimethoprim sulphamethoxazole, TUL: Tulathromycin, TY: Tylosin

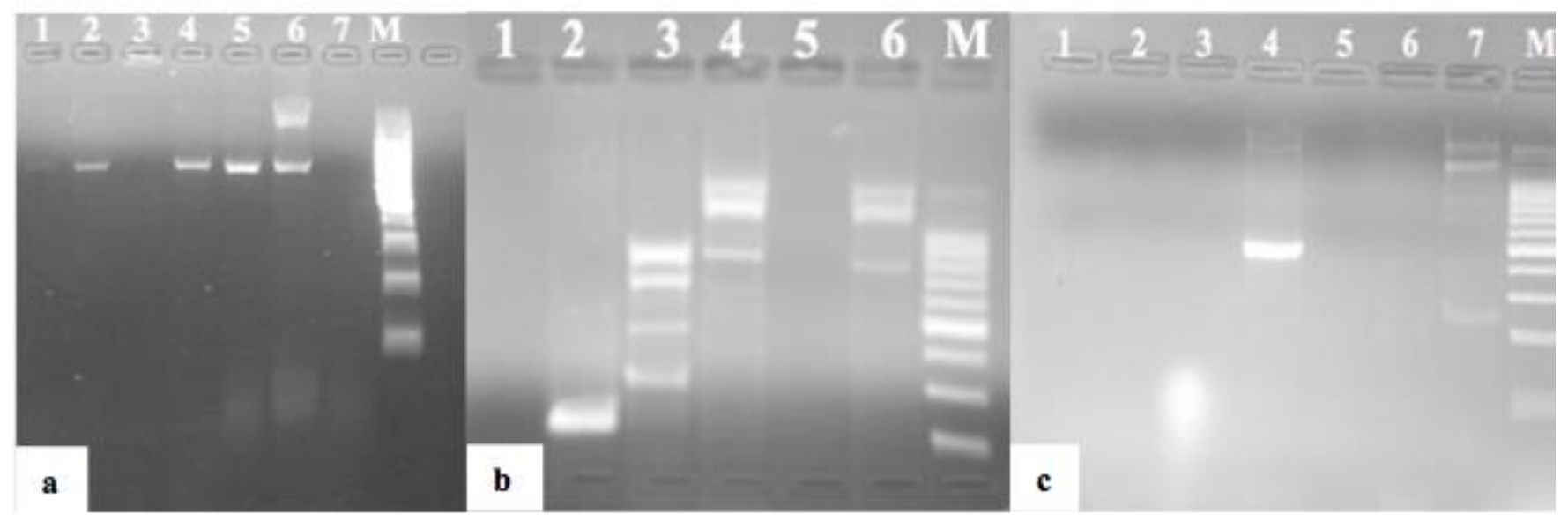

Figures 1. Multiplex PCR assay was performed using Group I-II-III Tcr primers respectively. M: 100bp marker; 1, 2, 4, 5: tet (B), 6: tet (B) and (D); 2: tet (A), 3, 4, 6: tet (G); 4: tet(M), 7: tet (L) 


\section{DISCUSSION}

G. anatis is commonly found among normal flora of both the upper respiratory tract and lower genital tract of chickens and other avian species, and can therefore be regarded as an opportunistic pathogen. The pathogenesis of $G$. anatis is not well-characterized, particularly at the molecular level, and little is known about which antibiotic resistace, genes and mechanisms are associated with the ability of $G$. anatis to cause disease.The current investigation is the first study of the antimicrobial resistance, tet and virulence genes of $G$. anatis in Turkey. Among the 20 isolates tested, the highest antimicrobial resistance patterns were observed for erythromycin, streptomycin, tilmicosin $(100 \%)$ followed by colistin sulphate $(65 \%)$, cephalexin and tulathromycin (50\%) which are shown in table 3 The majority of the isolates were exhibited susceptibility against to amoxicillin clavulanic acid, ceftiofur, enrofloxacin, florfenicol, gentamicin, trimethoprim sulphamethoxazole which is in agreement with the other studies (Jones et al., 2013; ElBastawy, 2014; El-Adawy et al., 2018; Lawal et al., 2018). About $100 \%$ of the G. anatis isolates exhibited sensitivity to doxycilline while $15 \%$ and $85 \%$, respectively, showed intermediate resistance to tetracycline. Especially high level of tetracycline resistance was similar with the previous researches (Bojesen et al., 2011b; Jones et al., 2013; Abd El-Hamid et al., 2016; Lawal et al., 2018). In contrast to these findings, Lin et al. (2001) also reported moderate sensitivity to tetracycline. Multi-drug resistance reveals that 13 isolates representing large percentage $(65 \%)$ resistance against three or more antibiotics. Especially, MDR patterns in this study were similar to those observed in previous study (Bojesen et al., 2011b). In this study, singleplex and multiplex PCR were used to detect Tcr and virulence genes in $G$. anatis isolates from laying hens. This study can be one of the first tries to examine the prevalence of these genes in G. anatis isolates in Turkey and also to test for the presence of tet $(\mathrm{P}),(\mathrm{Q})$, $(\mathrm{S})$, and $(\mathrm{X})$ in addition to the previously studied tet $(\mathrm{A})$, (B), (C), (D), (E), (G), (H), (K), (L), (M) and (O) genes (Hansen et al., 1993; Bojesen et al., 2011b). Four multiplex PCR groups were used in this study to detect 14 tetracycline resistance genes and singleplex PCR to target virulence-associated gtxA and flfA genes. Twenty isolates of $G$. anatis contained $10(50 \%)$ carried genes for tetracycline resistance, $7(35 \%)$ had tet(B), $2(10 \%)$ had $\operatorname{tet}(\mathrm{G})$, and $1(5 \%)$ had $\operatorname{tet}(\mathrm{A}),(\mathrm{D}),(\mathrm{M})$ or $(\mathrm{L})$. Another 2 $(10 \%)$ carried both $\operatorname{tet}(\mathrm{B})$ and $\operatorname{tet}(\mathrm{G})$ while $1(5 \%)$ had
tet(B), (D) and (A) genes. None of the other resistance genes were detected. Together, $\operatorname{tet}(\mathrm{A}),(\mathrm{B}),(\mathrm{D}),(\mathrm{G}),(\mathrm{M})$ and (L) genes, which are associated with efflux and/or ribosomal protection mechanisms of $G$. anatis were detected ( $\mathrm{Ng}$ et al., 2001; Michalova et al., 2004). Unsuprisingly, presence of these genes was explained according to the previous studies (Kehrenberg et al., 2001; Kehrenberg et al., 2006; Bojesen et al., 2011b). It is indicated that group I tet(B) genes had the most numbers among the 20 isolates, which is consistent with a report by Bojesen et al. (2011b). The tet(B) gene compared to the others, represented especially among Enterobacteriaceae (Roberts, 1996; Levy, 1998; Kehrenberg et al., 2006) and reported to be widely distributed among Pasteurellacea (Vaca et al., 2011; Lucio et al., 2012; Bager et al., 2013; Kudirkiene et al., 2014; Persson and Bojesen 2015; Zhang et al., 2017). The pathogenicity of $G$. anatis is influenced by various factors encoded by different virulence genes that play important roles in different pathogenic activities such as adhesion, invasion, intracellular survival, systemic infection, and toxin production (Kristensen et al., 2011; Persson and Bojesen, 2015; Sorour et al., 2015; Sing et al., 2016). In particular, the gtx toxin is responsible for the hemolytic and leukotoxic affects of $G$. anatis (Bager et al., 2013; Kudirkiene et al., 2014; Persson and Bojesen, 2015). The flfA gene is also implicated in G. anatis virulence and is a target for prevention of diseases caused by $G$. anatis in laying hens (Bager et al., 2013; Kudirkiene et al., 2014; Persson and Bojesen 2015). PCR amplification of these genes ( $g t x A$ and $f l f A)$ in this study showed that $6(30 \%)$ of the tested strains carried $g t x A$, but none had flfA. All of the isolates in this study displayed hemolytic characteristics, which is consistent with the expectations about the value of detecting $g t x$ for determination of pathogenic activity. A previous study that focused on hemolytic strains of $G$. anatis found that gtx was present in 7/12 (58\%) and 5/13 $(38.4 \%)$ samples from chickens and ducks, respectively (Sorour et al., 2015). Meanwhile, a study by Kristensen et al. (2011) revealed that gtx is associated with nonhemolytic $G$. anatis strains. The other studies found high incidences (50-75\%) of flfA gene (Kudirkiene et al., 2014; Sorour et al., 2015), whereas none of the isolates in present study had flfA. Moreover, the absence of fimbria in the isolates that examined could have contributed to the lower pathogenicity of these $G$. anatis strains. The findings of this study indicated no correlation between the presence of Tcr genes and genes associated with virulence in the isolates tested. The virulence mechanisms 
associated with the ability of $G$. anatis, which is typically a non-pathogenic component of the normal respiratory microflora of animals, to induce opportunistic respiratory tract infections under conditions that compromise immune responses or those that cause stress, such as inadequate nutritional intake (Bojesen et al., 2003), require further investigation.

\section{CONCLUSION}

The present study detected the genes associated with virulence and tetracycline resistance of Gallibacterium anatis that isolated from laying hens in Turkey for the first time and presented the first evidence to support the use of specific primers for tet $\mathrm{P}, \mathrm{Q}, \mathrm{S}$ and $\mathrm{X}$ genes in this breed. The findings of this study can increase the knowledge of Gallibacterium anatis pathogenicity in poultry.

\section{DECLARATIONS}

\section{Competing Interests}

The authors declare that they have no competing interests.

\section{Authors' Contributions}

OSY planned and designed the study. OSY performed the experiments, SY and OSY contributed to the analysis and interpretation of data. OSY drafted the manuscript. All authors read and approved the final manuscript.

\section{Acknowledgements}

We would like to thank Prof. Anders Miki Bojesen from from Department of Veterinary Disease Biology, University of Copenhagen, Denmark, for his valuable contributions (positive control strains maintenance and professional advices) to the study.

\section{REFERENCES}

Abd El-Hamid HS, Ellakany HF, Bekheet AA, Elbestawy AR and Mataried N (2016). Pathogenicity of ten Gallibacterium anatis isolates in commercial broiler chickens. Alexandria Journal of $\begin{array}{lll}\text { Veterinary } & \text { Sciences, } & \text { 49(2):42-49. }\end{array}$ https://doi.org/10.5455/ajvs.224857

Bager RJ, Nesta B, Pors SE, Soriani M, Serino L, Boyce JD, Adler B and Bojesen AM (2013). The fimbrial protein flfA from Gallibacterium anatis is a virulence factor and vaccine candidate. Infection and Immunity, 81(6): 1964-1973. DOI: https://doi.org/10.1128/IAI.00059-13

Bisgaard M, Korczak BM, Busse HJ, Kuhnert P and Bojesen AM (2009). Classification of the taxon 2 and taxon 3 complex of Bisgaard within Gallibacterium and description of Gallibacterium melopsittaci sp. nov., Gallibacterium trehalosifermentans sp. nov. and Gallibacterium salpingitidis sp. nov. International Journal of Systematic and Evolutionary Microbiology, 59(4): 735-744. DOI: https://doi.org/10.1099/ijs.0.005694-0.

Bojesen AM, Christensen JP, Nielsen OL, Olsen JE and Bisgaard M (2003). Detection of Gallibacterium spp. in chickens by fluorescent 16S rRNA in situ hybridization. Journal of Clinical Microbiology, 41(11): 5167-5172. DOI: https://doi.org/10.1128/jcm.41.11.51675172.2003

Bojesen AM, Kristensen BM and Pors SE (2011a). The role of the capsule in the pathogenesis of Gallibacterium anatis in chickens. In: (Eds.) International Pasteurellaceae Conference (Ipc), Elsinore.

Bojesen AM, Nielsen OL, Christensen JP and Bisgaard M (2004). In vivo studies of Gallibacterium anatis infection in chickens. Avian Pathology, 33(2):145-152. DOI: https://doi.org/10.1080/03079450310001652059

Bojesen AM, Vazquez ME, Bager RJ, Ifrah D and Gonzalez C (2011b). Antimicrobial susceptibility and tetracycline resistance determinant genotyping of Gallibacterium anatis. Veterinary Microbiology, 148(1): 105-110. DOI: https://doi.org/10.1016j. vetmic.2010.08.011

Chaveza RFO, Barriosa RMM, Chaveza JFH, Mascarenoa JR, Escalantea JGAI and Yanesb MA (2017). First report of biovar 6 in birds immunized against Gallibacterium anatis in poultry farms located in Sonora, Mexico. Veterinaria México, 4(3):1-8. DOI: https://doi.org/10.21753/vmoa.4.3.389

Clauer PJ (2009). Why have my hens stopped laying? Poultry Extension Specialist, Animal and Poultry Sciences. Available at: http://www.pubs.ext.vt.edu/content/ Accessed 29 April 2018.

El-Adawy H, Bocklisch H, Neubauer H, Hafez HM and Hotzel H (2018). Identification, differentiation and antibiotic susceptibility of Gallibacterium isolates from diseased poultry. Irish Veterinary Journal, 71 (5):1-10. DOI: https://doi.org/10.1186/s13620-018$\underline{0116-2}$

El-Bestawy AR (2014). Studies on Gallibacterium anatis infection in chickens. Ph.D Thesis in Poultry Diseases, Alexandria University, Egypt.

Hansen LM, Mcmurry LM, Levy SB and Hirsh DC (1993). A new tetracycline resistance determinant, Tet $\mathrm{H}$, from Pasteurella multocida specifying active efflux of tetracycline. Antimicrobial Agents Chemotherapy, 37(12): 2699-2705. DOI: https://doi.org/10.1128/aac.37.12.2699.

Johnson TJ, Danzeisen JL, Trampel D, Nolan LK, Seemann T, Bager RJ and Bojesen AM (2013). Genome analysis and phylogenetic relatedness of Gallibacterium anatis strains from poultry. PLOS ONE, $8(1)$ : $1-12 . \quad$ DOI: https://doi.org/10.1371/journal.pone.0054844.

Jones KH, Thornton JK, Zhang Y and Mauel MJ (2013). A 5-year retrospective report of Gallibacterium anatis and Pasteurella multocida isolates from chickens in Mississippi. Poultry Science, 92(12): 3166-3171. DOI: https://doi.org/10.3382/ps.2013-03321.

Kehrenberg C, Salmon SA, Was JL and Schwarz S (2001). Tetracycline resistance genes in isolates of Pasteurella multocida, Mannheimia haemolytica, Mannheimia glucosida and Mannheimia varigena from bovine and swine respiratory disease: intergeneric spread of the $\operatorname{Tet}(\mathrm{H})$ plasmid pMHT1. Journal of Antimicrobial Chemotherapy, 48(5): 631-640. https://doi.org/10.1093/jac/48.5.631

Kehrenberg C, Walker RD, Wu CC and Schwarz S (2006). Antimicrobial resistance in members of the family Pasteurellaceae. In:Aarestrup FM (Ed.), Antimicrobial resistance in bacteria of animal origin. Asm Press, Washington, DC, pp. 167-183. Available at: https://www.asmscience.org/content/journal/microbiolspec/10.1128 Imicrobiolspec.ARBA-0022-2017 
Kristensen BM, Frees D and Bojesen AM (2011). Expression and secretion of the RTX-toxin GtxA among members of the genus Gallibacterium. Veterinary Microbiology, 153(1-2): 116123. DOI: https://doi.org/10.1016/j.vetmic.2011.05.019.

Kudirkiene E, Bager RJ, Johnson TJ and Bojesen AM (2014). Chaperone-usher fimbriae in a diverse selection of Gallibacterium genomes. BMC Genomics, 12(15): 1-13 DOI: https://doi.org/10.1186/1471-2164-15-1093.

Lawal JR, Ndahi JJ, Dauda J, Gazali YA, Gadzama JJ and Aliyu AU (2018). Survey of Gallibacterium anatis and its antimicrobial susceptibility pattern in village chickens (gallus gallus domesticus) in Maiduguri, North-Eastern Nigeria. Direct Research Journal of Veterinary Medicine and Animal Science, $1(1)$ : 93-105. DOI: https://doi.org/10.31021/ijvam.20181101

Levy SB, Mcmurray LM, Barbosa TM, Burdett V, Courvalin P, Hillen W, Roberts MC, Rood JI and Taylor DE (1989). Nomenclature for new tetracycline resistance determinants. Antimicrobial Agents $\begin{array}{llll}\text { Chemotherapy, } & 33(8), & 1373-1374 . & \text { DOI: }\end{array}$ https://doi.org/10.1128/AAC.43.6.1523

Lin MY, Lin KJ, Lan YC, Liaw MF and Tung MC (2001). Pathogenicity and drug susceptibility of the Pasteurella anatis isolated in chickens in Taiwan. Avian Disease, 45(3):655-658. Available at: https://pubmed.ncbi.nlm.nih.gov/11569739/

Lucio MLS, Vaca S, Vazquez C, Zenteno E, Rea I, Perez-Marquez VM and Negrete-Abascal E (2012). Adhesion of Gallibacterium anatis to chicken oropharyngeal epithelial cells and the identification of putative fimbriae. Advance Microbiology, 2(4):505-510. DOI: https://doi.org/10.4236/aim.2012.24064

Marshall BM, Tachibana C and Levy SB (1982). Frequency of tetracycline resistance determinant classes among lactosefermenting coliforms. Antimicrobial Agents Chemotherapy, 24:835-840. DOI: https://doi.org/10.1128/aac.24.6.835

Michalova E, Novotna P and Schlegelova J (2004). Tetracyclines in veterinary medicine and bacterial resistance to them. $\begin{array}{lll}\text { Veterinary Medicine, 49(3):79-100. DOI: } & \end{array}$ https://doi.org/10.17221/5681-VETMED

National Committee for Clinical Laboratory Standards (CLSI) (2017). Performance Standards for Antimicrobial Disk Susceptibility Tests. 27th Ed. Clsi Supplement M100. National Committee for Clinical Laboratory Standards Institute, Wayne, Pa. Available at: http://file.qums.ac.ir/repository/mmrc/clsi\%202017.pdf

Ng LK, Martin I, Alfa M and Mulvey M (2001). Multiplex PCR for the detection of tetracycline genes. Molecular and Cellular Probes, 15(4): 209-215. DOI: https://doi.org/10.1006/mcpr.2001.0363

Paudel S, Alispahic M, Liebhart D, Hess M and Hess C (2013). Assessing pathogenicity of Gallibacterium anatis in a natural infection model: the respiratory and reproductive tracts of chickens are targets for bacterial colonization. Avian Pathology, 42(6): 527535. DOI: https://doi.org/10.1080/03079457.2013.843160.
Persson G and Bojesen AM (2015). Bacterial determinants of importance in the virulence of Gallibacterium anatis in poultry. Veterinary Research, 46(57): 1-11. DOI: https://doi.org/10.1186/s13567-0150206-Z.

Roberts MC (1996). Tetracycline resistance determinants: mechanisms of action, regulation of expression, genetic mobility, and distribution. Fems Microbiology Review, 19:1-24. DOI: https://doi.org/10.1111/j.1574-6976.1996.tb00251.x

Rzewuska M, Karpinska E, Szeleszczuk P and Binek M (2007). Isolation of Gallibacterium spp. from peacocks with respiratory tract infections. Medycyna Weterynaryjna, 63(11): 1431-1433. Available at:http://www.medycynawet.edu.pl/images/stories/pdf/pdf2007/11sup2007/2 00711supl14311433.pdf

Schwarz S, Silley P, Simjee S, Woodford N, Van Duijkeren E, Johnson AP and Gaastra W (2010). Editorial: assessing the antimicrobial susceptibility of bacteria obtained from animals. Journal of Veterinary Medicine and Animal Science, 65(4): 601-604. DOI: https://doi.org/10.1093/jac/dkq037.

Sing SV (2016). Studies on growth kinetics of Gallibacterium anatis in presence of deuterium oxide (D2O, Heavy Water). Thesis of Master Degree. Deemed University Icar-Indian Veterinary Research Institute Izatnagar, India. Available at: https://krishikosh.egranth.ac.in/displaybitstream?handle=1/5810097 $\underline{010}$

Sorour HK, Al Atfeehy NM and Shalaby AG (2015). Gallibacterium anatis infection in chickens and ducks. Assiut Veterinary Medical Journal, 61(147): 80-86.

Tenover FC, Leblanc DJ and Elvrum P (1987). Cloning and expression of a tetracycline resistance determinant from Campylobacter jejuni in Escherichia coli. Antimicrobial Agents and Chemotherapy, 31(9): 1301-1306. DOI: https://doi.org/10.1128/aac.31.9.1301

Vaca S, Monroy E, Rojas L, Vazquez C, Sanchez P, Soriano-Vargas E, Bojesen AM and Negrete- Abascal E (2011). Adherence of Gallibacterium anatis to inert surfaces. Journal of Animal and Veterinary Advances, 10: 1688-1693. DOI: https://doi.org/10.3923/javaa.2011.1688.1693

Yaman S and Sahan Yapicier O (2019). Diagnosis of Gallibacterium anatis in layers: First report in Turkey. Brazilian Journal of Poultry Science, 21(3): 1-8. DOI: https://doi.org/10.1590/1806-9061-2019$\underline{1019}$

Zhang XP, Lu CJ, Li YT, Yang X, Wang XW, Chang HT, Liu HY, Chen L, Zhao J, Wang CQ and Chang YF (2017). In vitro adherence and invasion of primary chicken oviduct epithelial cells by Gallibacterium anatis. Veterinary Microbioloy, 203:136-142. DOI: https://doi.org/10.1016/j.vetmic.2017.02.009.

Zhao J and Aoki T (1992). Nucleotide sequence analysis of the class G tetracycline resistance determinant from Vibrio anguillarum. Microbiology and Immunology, 36(10): 1051-1060. DOI: https://doi.org/10.1111/j.1348-0421.1992.tb02109.x 